\title{
Comparison of antimicrobial susceptibility, $\beta$-lactamase production, plasmid analysis and serum bactericidal activity in Edwardsiella tarda, E. ictaluri and E. hoshinae
}

\author{
P. J. REGER, DIANNE F. MOCKLER* and MARCIA A. MILLER* ${ }^{*}$ \\ - Belleville Family Practice, Belleville, Illinois and "Department of Basic Sciences, University of Illinois College of \\ Medicine at Peoria, Peoria, IL, 61656, USA
}

\begin{abstract}
Summary. Antimicrobial susceptibility profiles of clinical and environmental isolates of Edwardsiella demonstrate that the three species are susceptible to $\beta$-lactam antibiotics. All strains were susceptible to two quinolones tested and to gentamicin and doxycycline. E. tarda and $E$. hoshinae were resistant to clindamycin, whereas $E$. ictaluri was moderately susceptible. $\beta$-Lactamase was produced by all strains of $E$. tarda, but not by $E$. hoshinae or E. ictaluri. A 54-kb plasmid was detected in six of 13 E. hoshinae strains. Five of the 10 E. tarda isolates studied gave an identical plasmid pattern of four plasmids ranging in size from $76-\mathrm{kb}$ to $5 \cdot 0$ $\mathrm{kb}$. One strain exhibited a $54-\mathrm{kb}$ plasmid; four strains did not contain plasmid DNA. All $E$. ictaluri isolates contained a $5 \cdot 7-\mathrm{kb}$ and a $4 \cdot 9-\mathrm{kb}$ plasmid. E. tarda and E. ictaluri strains were resistant to human serum $20 \% ; 12$ of 13 strains of $E$. hoshinae were also serum resistant. Serum resistance may play an important part in the pathogenicity of these species.
\end{abstract}

\section{Introduction}

Edwardsiella, a relatively unstudied genus in the family Enterobacteriaceae, is a motile, facultative anaerobic rod without the ability to ferment most carbohydrates. ${ }^{1}$ Three species have been identified to date-E. tarda, E. ictaluri and E. hoshinae. The last species has only been recognised since 1980 , after displaying the ability to ferment D-mannitol, D-trehalose and sucrose and salicin, in contrast to the other two species. ${ }^{2}$ The three species have been isolated primarily from aquatic and cold-blooded animals; however, warm-blooded animals, including man, have been documented as harbouring the organisms. ${ }^{3-6}$

$E$. tarda and E. ictaluri have been associated with infective disease. In man, E. tarda is an opportunist pathogen; most infections are acquired exogenously. E. tarda causes gastro-enteritis marked primarily by diarrhoea. ${ }^{4,-8}$ The diarrhoea may result from a heatstable enterotoxin, although initial research indicates it to be more like the enterotoxin produced by Salmonella spp, which is of secondary pathogenic importance to the invasiveness of the bacterium. ${ }^{10}$ Cases of gastro-enteritis have been associated with nausea, vomiting, enteric fever and abdominal pain secondary to the infection. ${ }^{3.7 \cdot 10-12}$ Extra-intestinal diseases are uncommon, but include hepatic abscesses, meningitis, wound infections, bacteraemia and osteomyelitis. ${ }^{8,11-13}$

Received 22 Sept. 1992; accepted 9 March 1993. $\dagger$ Correspondence should be sent to Professor M. A. Miller.
The majority of pathogenicity studies, including antibiotic susceptibility studies and plasmid analysis, have been performed on $E$. tarda. This species is generally susceptible to those antimicrobial agents active against gram-negative bacteria, with the exception of colistin and polymyxin B. ${ }^{14-16} \mathrm{R}$ plasmids conveying resistance to sulphonamide and tetracycline, or sulphonamide, tetracycline, streptomycin, kanamycin and chloramphenicol have been isolated from $E$. $\operatorname{tarda},{ }^{17}$ as well as a 123 -kb plasmid of unknown content.$^{18} \mathrm{~A}$ class $\mathrm{D}$ plasmid carrying tetracycline resistance alone, commonly found in marine and freshwater fish pathogens, ${ }^{19}$ has also been reported.

E. ictaluri, primarily associated with enteric septicaemia of channel catfish, ${ }^{20,21}$ is the leading cause of bacterial mortality in Mississippi delta catfish. Human pathogenicity has not been established to date. ${ }^{19}$ Two plasmids have been identified, $5 \cdot 7 \cdot \mathrm{kb}$ and $4 \cdot 9-\mathrm{kb}$. Their significance has not been established, ${ }^{20}$ but they are thought to harbour important virulence factors, or relate to metabolic processes. Its apparent lack of pathogenicity in man is likely to result from the relative absence of research on the species, or failure to recognise it in the clinical laboratory, as its biochemical profile is extremely close to that of E. tarda.

In 1980, E. hoshinae was established as a third species in the genus Edwardsiella. E. hoshinae isolates have been found in birds, reptiles and water. ${ }^{2}$ Rarely, isolates from human faeces have been reported in patients without evidence of disease. ${ }^{1}$ Because of its similarity to $E$. tarda, it might be expected to have a similar potential for disease in man. However, since 
little work has been done on the species, its pathogenic potential is unknown. At least one study has shown evidence for entero-invasiveness. ${ }^{22}$

The potential exists for all three species of Edwardsiella to play a role in diarrhoeal disease, especially for individuals in wildlife or fish management and food processing occupations. Therefore, the specific aims of this study included: a comparative antibiotic susceptibility profile to determine antimicrobial agents that may be therapeutically useful; determination of $\beta$-lactamase production; assessment of the ability of the bacteria to survive serum bactericidal activity, a primary host defence against infection; and analysis of plasmids as potential carriers of antibiotic resistance and virulence factors. An investigation of these areas may better define the pathogenic potential of these bacteria, especially as Edwardsiella spp. and related bacteria are found in immunocompromised patients. ${ }^{23,24}$

\section{Materials and methods}

\section{Bacterial strains}

Ten strains each of $E$. tarda and $E$. ictaluri and 13 strains of $E$. hoshinae were studied. The strain designations and sources are listed in table I. Stock cultures were frozen at $-76^{\circ} \mathrm{C}$ in Trypticase Soy Broth (TSB; Difco) with dimethyl sulphoxide (DMSO) $10 \%$. Four of the isolates were duplicates, acquired from different laboratories: 9-66, 10-78, 2-78 (ATCC 33379) and 1066 (ATCC 35051).

\section{Identification methods}

Routine microbiological testing procedures were used to confirm the species identification of the $E$. hoshinae, E. tarda and E. ictaluri strains. Grimont et $a l^{2}$ described criteria to differentiate $E$. hoshinae from similar species, including malonate utilisation and acid production from sucrose, D-trehalose and salicin. These criteria were followed in conjunction with the API 20E System (Analytab Products Inc., Plainview, New York) for each isolate. Morphological characteristics of E. tarda and E. hoshinae were obtained by growth on Trypticase Soy Agar (TSA; Difco) plates at $37^{\circ} \mathrm{C}$ incubated for $24 \mathrm{~h}$ and visualised by light microscopy. E. ictaluri isolates were grown at $25^{\circ} \mathrm{C}$ for $24-48 \mathrm{~h}$.

The malonate utilisation test was performed by the modified Ewing malonate procedure. ${ }^{25}$ Glucose $0.025 \%$ and yeast extract were added to stimulate initial growth of the organisms.

\section{Antimicrobial susceptibility testing}

The choice of antimicrobial agents was based on previously published susceptibility profiles of $E$. tarda and $E$. ictaluri and the potential efficacy of certain antibiotics in gastro-intestinal infections. ${ }^{14,16,26.27}$ Antimicrobial susceptibility test powders were obtained as follows: aztreonam (E. R. Squibb and Sons); ampicillin (Bristol Laboratories); piperacillin (Lederle Laboratories); imipenem (Merck, Sharp and Dohme); cefotaxime (Hoechst-Roussel Pharmaceuticals) ; ciprofloxicin (Miles); norfloxacin (Merck, Sharp and Dohme); clindamycin- (UpJohn); gentamicin (Schering) and doxycycline (Pfizer).

A modification of the standard broth dilution method of the National Committee for Clinical Laboratory Standards ${ }^{28}$ employing an inoculum of $5 \times 10^{3}$ cfu was used to determine minimum inhibitory (MIC) and bactericidal (MBC) concentrations. E. ictaluri isolates required incubation for $48 \mathrm{~h}$ at $25^{\circ} \mathrm{C}$ for visualisation of growth; this extended incubation period did not appear to affect adversely the result of susceptibility testing.

Serial two-fold broth dilutions were performed in Mueller Hinton Broth (MHB; Difco) for clindamycin, gentamicin and doxycycline. The range of concentrations was based on MICs previously reported for Edwardsiella and related species. ${ }^{15,16}$ Two-fold broth dilutions for the remaining antibiotics, from $1.0 \mathrm{mg} / \mathrm{L}$ to $10 \mathrm{ng} / \mathrm{L}$, were performed based on the results of preliminary 10 -fold range-finding screenings (spot MICs). The MIC was defined as the lowest concentration of antibiotic at which no turbidity was observable; the $\mathrm{MBC}$ was the lowest concentration of the antibiotic from which a $99.9 \%$ reduction in the initial bacterial inoculum occurred. ${ }^{29}$

\section{$\beta$-lactamase testing}

Four methods were used to detect $\beta$-lactamase: (1 and 2) chromogenic cephalosporin test as developed by O'Callaghan et al., ${ }^{30}$ utilising both whole cell suspensions (test 1 ) and cell suspensions, ${ }^{31}$ which had been sonicated for $5 \mathrm{~min}$ in 1 -min bursts at $20 \mathrm{kc} / \mathrm{s}(45 \%$ intensity) (test 2); (3) the rapid acidometric method,32,33 and (4) the Nitrocefin disk diffusion technique. $^{34}$ Cefinase $^{\mathrm{TM}}$ disks (BBL Microbiology Systems) were used according to the manufacturer's instructions.

\section{Serum bactericidal activity}

The bactericidal activity of serum against $E$. tarda, E. ictaluri and E. hoshinae was measured by the method of Wiemer et al. ${ }^{35}$ Fresh whole blood was obtained with consent from healthy volunteers from the University of Illinois College of Medicine at Peoria. Pooled serum was frozen at $-70^{\circ} \mathrm{C}$ in $2-\mathrm{ml}$ volumes and thawed immediately before use. Heat inactivated serum was used as a growth control. A strain was considered to be serum sensitive if there was at least a 10 -fold decrease in viable counts between time zero and $120 \mathrm{~min}$ as compared to the control; resistant strains demonstrated growth, or no change in counts from the original inoculum. ${ }^{36}$ 
Table I. Source of Edwardsiella strains

\begin{tabular}{|c|c|c|c|}
\hline Species & Strain no. & Specimen & Source \\
\hline \multirow[t]{10}{*}{ E. $\operatorname{tarda}$} & 11 & NA & 1 \\
\hline & 16 & Stool & 1 \\
\hline & 3276 & Stool & 1 \\
\hline & 1079 & Stool & 1 \\
\hline & 11277 & Stool & 1 \\
\hline & 51778 & Stool & 1 \\
\hline & 1228417 & Stool & 1 \\
\hline & 1230008 & Stool & 1 \\
\hline & HVA643 & Stool & 1 \\
\hline & HVA986 & Sputum & 1 \\
\hline \multirow{10}{*}{ E. ictaluri } & AL-5 & Channel catfish & 2 \\
\hline & 1354 & Channel catfish & 2 \\
\hline & 6012 & Channel catfish & 3 \\
\hline & 6013 & Channel catfish & 3 \\
\hline & 33202 & Channel catfish & 2 \\
\hline & S89-514 & Channel catfish-kidney & 4 \\
\hline & S89-520 & Channel catfish-kidney & 4 \\
\hline & S89-521 & Channel catfish-kidney & 4 \\
\hline & S87-661 & Channel catfish-kidney & 4 \\
\hline & S87-637 & Channel catfish-kidney & 4 \\
\hline \multirow[t]{13}{*}{ E. hoshinae } & $1-78$ & Male puffin & 1 \\
\hline & EH-1 & NA & 1 \\
\hline & 9-66 (dry) & Monitor lizard & 1 \\
\hline & ATCC 33379 & Female puffin & 1 \\
\hline & ATCC 35051 & NA & 1 \\
\hline & $2-78$ & Female puffin & 5 \\
\hline & $2-66$ & Monitor lizard & 5 \\
\hline & $9-66$ & Monitor lizard & 5 \\
\hline & $10-66$ & Monitor lizard & 5 \\
\hline & $12-67$ & Lizard & 5 \\
\hline & $1-78$ & Male puffin & 5 \\
\hline & $3-78$ & Flamingo & 5 \\
\hline & $420-72$ & Water & 5 \\
\hline
\end{tabular}

NA, not available.

1, J. M. Janda, California State Department of Health Service, Berkeley, CA; 2, C. Lobb, University of Mississippi ; 3, E. Shotts, University of Georgia (courtesy of J. M. Janda); 4, T. Santucci Mississippi Cooperative Service, Stoneville, MS (courtesy of S. Hayasaka, Clemson University); 5, P. A. D. Grimont, Pasteur Institute, Paris.

\section{Plasmid screening}

Two methods were used to extract plasmid DNA. Strains were initially screened for plasmid DNA by the methods of Kado and $\mathrm{Liu}^{37}$ and that of Portnoy and White. ${ }^{38-40}$

Agarose gel electrophoresis was performed according to the method of Meyers et al.,${ }^{41}$ with 15- $\mu$ l samples separated through agarose $0.7 \%$ gel.

Approximate plasmid size was determined by interpolation of plots of the $\log$ of the mol. wt versus relative mobility of reference strains harbouring known plasmids of both low and intermediate mol. wt ranging from $1 \cdot 9-\mathrm{kb}$ to $54-\mathrm{kb}^{42}$

\section{Light and electronmicroscopy}

Light microscopy (American Optical 150 microscope) was used to examine isolates for antibioticinduced morphological alterations. ${ }^{43}$ Ten $1000 \times$ oilimmersion fields were examined for each strain, at each of 10 antibiotic concentrations. Elongation and filamentation were defined according to Lorian $:^{44}$ a bacillus was considered to be elongated when the cell length had at least doubled. A rod which was $>10 \mu \mathrm{m}$ in length was considered to be a filament.

Imipenem was used to evaluate morphological defects by transmission electronmicroscopy. Cell suspension of strain EH-1 in concentrations of imipenem from 7.8-156 $\mu \mathrm{g} / \mathrm{L}$ (one and two tubes below the MIC, respectively) were used as a representative isolate. Standard electronmicroscopy procedures for embedding dehydrating, sectioning and staining were employed. ${ }^{45.46}$

\section{Results}

\section{Identification}

All colonies grown on TSA were flat, small $(0 \cdot 5-$ $2 \mathrm{~mm}$ in diameter) and clear with smooth borders. However, E. hoshinae strain 9-66 from Janda exhibited a colony that was initially a more dry and friable consistency compared to strain 9-66 obtained from Grimont. The results of biochemical characterisation of the isolates with the API $20 \mathrm{E}$ system and conventional biochemical tests are summarised in table II. $E$. ictaluri isolates were incubated for $48 \mathrm{~h}$ at $25^{\circ} \mathrm{C}$ and $37^{\circ} \mathrm{C}$. Citrate was utilised by E. ictaluri isolates at $25^{\circ} \mathrm{C}$ but not at $37^{\circ} \mathrm{C}$. Lysine decarboxylase activity was variable; all other biochemical tests gave equivocal results at both temperatures.

The ability of $E$. hoshinae to utilise sodium malonate as a sole carbon source is a major character differentiating this species from E. tarda and E. ictaluri. $^{2}$ All $E$. hoshinae isolates were malonate positive; $E$. tarda and $E$. ictaluri isolates were malonate negative.

\section{Antimicrobial susceptibility testing and morphological defects}

All the Edwardsiella isolates were susceptible to the five $\beta$-lactams tested (MIC $\leqslant 0.31 \mathrm{mg} / \mathrm{L}$ ), with greatest sensitivity to cefotaxime and aztreonam (MICs $<0.01 \mathrm{mg} / \mathrm{L}$ ) (table III). Imipenem had the highest MIC values of any $\beta$-lactam antibiotic tested against $E$. ictaluri, but when achievable blood levels were taken into account this was not significant.

The three Edwardsiella spp. were exquisitely susceptible to the quinolones. Ciprofloxacin had at least a 100 -fold greater activity against $E$. tarda and $E$. ictaluri than against $E$. hoshinae. Gentamicin and doxycycline MICs were $\leqslant 0.625 \mathrm{mg} / \mathrm{L}$. Clindamycin resistance was demonstrated in $E$. tarda and $E$. hoshinae; $E$. ictaluri was moderately susceptible (table III).

The percentage of MICs equalling MBCs are summarised in table IV. Marked variability was noted among the strains when comparing MICs versus MBCs for the $\beta$-lactam antibiotics. With the exception of $E$. ictaluri and ciprofloxacin, $90 \%$ of the MBCs equalled MICs for the quinolones. The inhibitors of protein synthesis also exhibited strain variability when comparing MICs to MBCs; none of the strains of E. tarda or E. ictaluri had MICs equal to MBCs for clinda- 
Table II. Biochemical characteristics of Edwardsiella isolates

\begin{tabular}{|c|c|c|c|c|}
\hline \multirow[b]{3}{*}{ Characteristic } & \multicolumn{4}{|c|}{ Results obtained with } \\
\hline & \multirow[b]{2}{*}{ E. $\operatorname{tarda}$} & \multicolumn{2}{|c|}{ E. ictaluri } & \multirow{2}{*}{ E. hoshinae } \\
\hline & & $25^{\circ} \mathrm{C}$ & $37^{\circ} \mathrm{C}$ & \\
\hline \multicolumn{5}{|l|}{ API20E } \\
\hline ONPG & - & - & - & - \\
\hline Arginine dihydrolase & - & - & - & - \\
\hline Lysine decarboxylase & + & $+^{*}$ & $+\dagger$ & + \\
\hline Ornithine decarboxylase & + & - & - & + \\
\hline Citrate & + & + & - & $+\ddagger$ \\
\hline $\mathrm{H}_{2} \mathrm{~S}$ & + & - & - & $+\S$ \\
\hline Urea & - & - & - & - \\
\hline Tryptophane deaminase & - & - & - & - \\
\hline Indole & + & - & - & + \\
\hline Voges-Proskauer (VP) & - & - & - & - \\
\hline Gelatin liquefaction & - & - & - & - \\
\hline Glucose & + & + & + & + \\
\hline Mannitol & - & - & - & + \\
\hline Inositol & - & - & - & - \\
\hline Sorbitol & - & - & - & - \\
\hline Rhamnose & - & - & - & - \\
\hline Sucrose & - & - & - & + \\
\hline Melibiose & - & - & - & - \\
\hline Amygdalin & - & - & - & - \\
\hline$(\mathrm{L}+)$ Arabinose & - & - & - & - \\
\hline \multicolumn{5}{|l|}{ Conventional biochemical tests } \\
\hline Malonate & - & & - & + \\
\hline$\beta$-Lactamase & + & & - & - \\
\hline
\end{tabular}

* Strains 514 and 637 gave negative results.

+ Strains AL5, 514 and 521 gave negative results.

‡ Strain 2-66 gave a negative result.

$\S$ Strains 490-72 and 9-66 gave negative results.

Table III. $\mathrm{MIC}_{50}$ and $\mathrm{MIC}_{90}$ for Edwardsiella species of a range of antibiotics

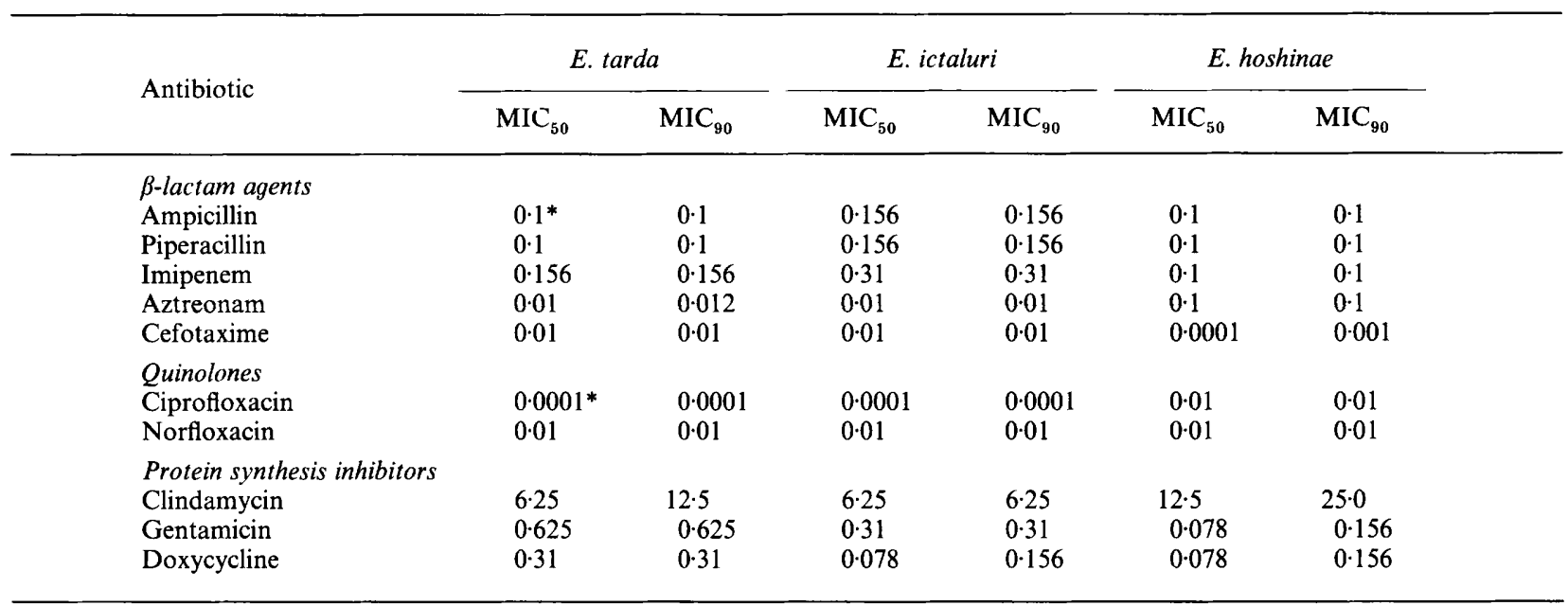

* mg/L.

mycin. However, compared to doxycycline and clindamycin, gentamicin exhibited the greatest bactericidal activity.

Characteristic $\beta$-lactam-induced morphological defects were observed : cell elongation at lower concentrations of antibiotic followed by gradual increase to mid-cell defects and spheroplasts as concentrations approached the MIC. Imipenem, with specific affinity for penicillin-binding protein 2 , caused formation of spheroplast structures at all concentrations, as expected (fig. 1A and B, fig. 2).

\section{$\beta$-lactamase production}

Irrespective of the method used, none of the $E$. ictaluri or $E$. hoshinae isolates produced $\beta$-lactamase in quantities detectable by our procedures. In contrast, all 10 strains of $E$. tarda exhibited $\beta$-lactamase activity with all methods.

\section{Serum bactericidal activity}

All strains of $E$. tarda and E. ictaluri were resistant to $20 \%$ serum; 12 of the 13 strains of $E$. hoshinae were 
Table IV. Relationship between MIC and MBC.

\begin{tabular}{lccc}
\hline & \multicolumn{3}{c}{ Percentage of MBCs equalling MICs for } \\
\cline { 2 - 4 } Antibiotic & E. tarda & E. ictaluri & E. hoshinae \\
\hline Ampicillin & 10 & 20 & 77 \\
Piperacillin & 20 & 50 & 77 \\
Imipenem & 50 & 60 & 62 \\
Aztreonam & 80 & 60 & 85 \\
Cefotaxime & 100 & 50 & 77 \\
Ciprofloxacin & 90 & 50 & 90 \\
Norfloxacin & 90 & 90 & 90 \\
Clindamycin & 0 & 0 & 10 \\
Gentamicin & 40 & 70 & 30 \\
Doxycycline & 0 & 40 & 8 \\
& & & \\
\hline
\end{tabular}

resistant (fig. 3). E. hoshinae strain 35051 was susceptible to the pooled human serum, with a 10 -fold decrease occurring after $120 \mathrm{~min}$ (fig. 4). Complete bactericidal activity did not occur, as viable organisms were recovered after $120 \mathrm{~min}$. Although $E$. hoshinae strains 35051 and 10-66 are the same but obtained from different laboratories, only strain 35051 exhibited serum susceptibility.

\section{Plasmid screening}

Although both the Kado and Liu, and the Portnoy and White methods of plasmid extraction were successful in the identification of plasmid DNA from our strains, the Portnoy method yielded clearer resolution of the individual plasmid DNA bands with less contamination by extraneous proteins (fig. 5).
Four plasmid bands were detected in five of the 10 E. tarda isolates screened (76-kb, 7.6-kb, 6.5-kb and $5 \cdot 0-\mathrm{kb}$ ). One isolate exhibited a single $54-\mathrm{kb}$ band; four $E$. tarda strains lacked plasmid DNA. All the $E$. ictaluri isolates contained a $5 \cdot 7-\mathrm{kb}$ and a $4 \cdot 9-\mathrm{kb}$ plasmid. Of the E. hoshinae isolates, six (46\%) of the 13 strains screened contained one plasmid of $c$. 54-kb. The remaining seven strains did not contain detectable plasmid DNA.

\section{Discussion}

Although the three species of Edwardsiella have been shown to be related by DNA-DNA hybridisation, ${ }^{1}$ there is no evidence to indicate that $E$. hoshinae or $E$. ictaluri has the same pathogenic potential as $E$. tarda. In this study, a collection of known strains of Edwardsiella spp. was examined by several procedures to assess pathogenic potential.

The antibiotics chosen for this study included those known to be effective in controlling bacteria capable of gastro-intestinal infection, most notably similar gramnegative pathogens, from our previous studies. ${ }^{47}$ Susceptibility profiles for $E$. hoshinae were similar to those of $E$. tarda and $E$. ictaluri for the $\beta$-lactam agents, quinolones and the protein synthesis inhibitors gentamicin and doxycycline. All showed marked susceptibility, especially to the quinolones. Both E. hoshinae and $E$. tarda were resistant to clindamycin (MIC $\geqslant 25$ $\mathrm{mg} / \mathrm{L}) ; E$. ictaluri exhibited moderate susceptibility.

Susceptibility to the $\beta$-lactams included the penicillins, a monobactam, a carbapenem and a third generation cephalosporin. The absence of $\beta$-lactamase
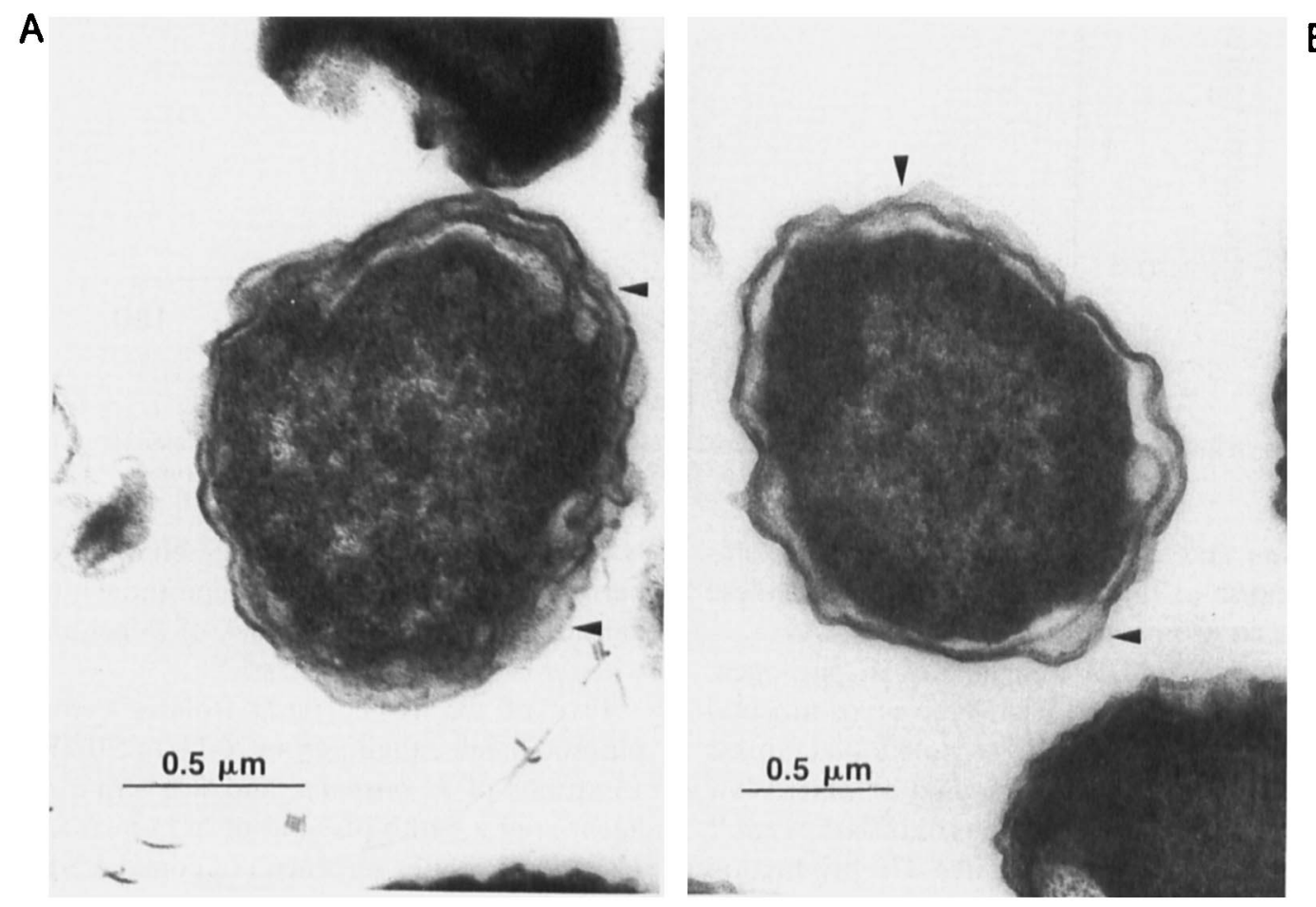

Fig. 1. Spheroplasts of E. hoshinae EH-1 induced by imipenem, which are at least twice the normal width of bacterial cells. The Tri-laminar outer wall structure has been lost due to antibiotic exposure $(\rightarrow)(A, \times 40000 ; B, \times 52000)$. 


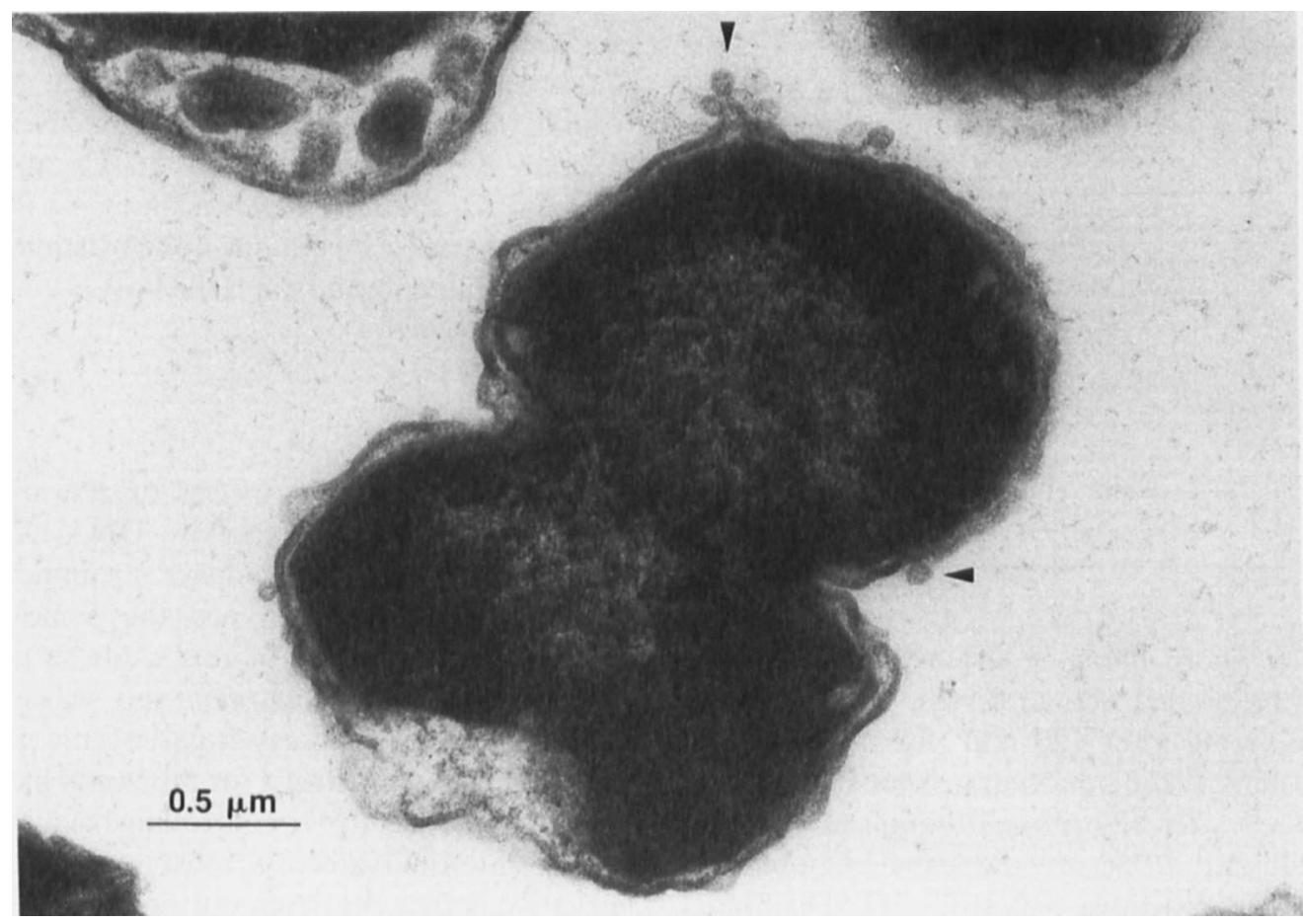

Fig. 2. Shedding of lipopolysaccharide from a spheroplast of $E$. hoshinae EH-1 the tri-laminar cell wall structure $(\times 65000)$

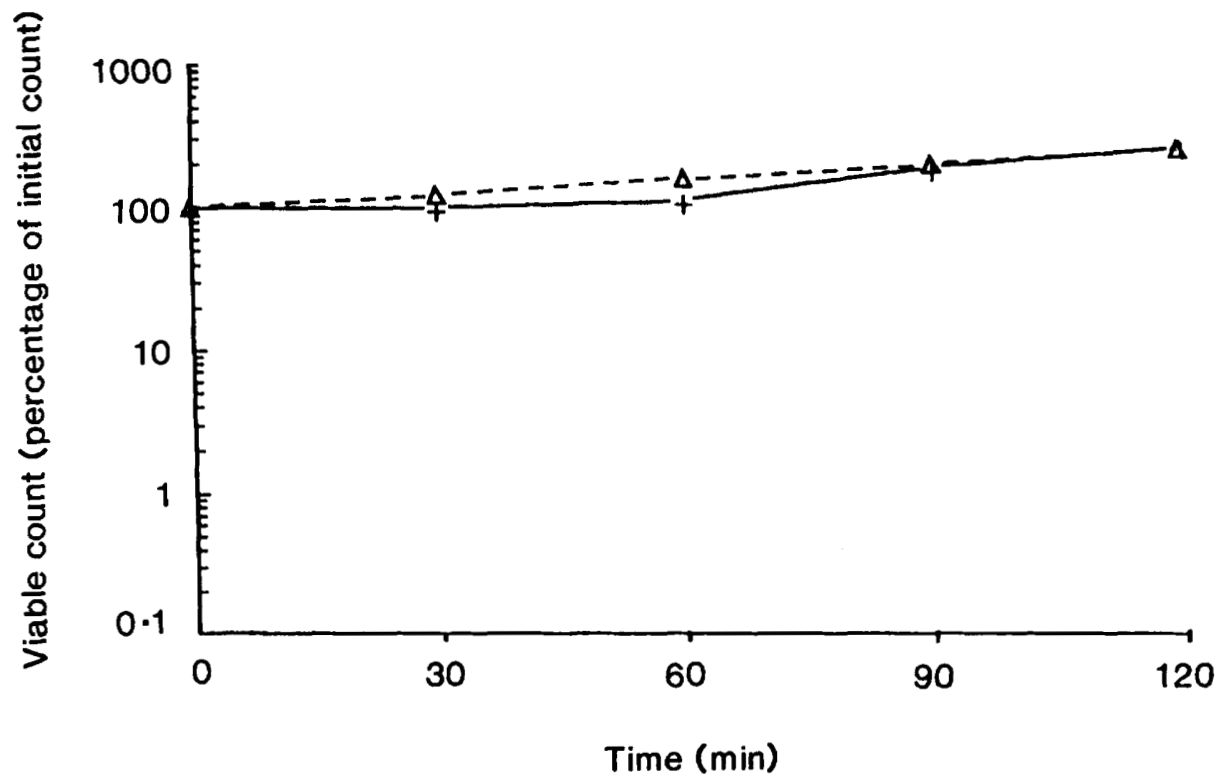

Fig. 3. Composite serum bactericidal susceptibility curves of $10 \mathrm{E}$. tarda isolates illustrating resistance to pooled human serum by the absence of a 10 -fold decrease in viable counts after $120 \mathrm{~min}$. PHS, $20 \%$ active serum $(-+-)$; HIS, $20 \%$ inactivated serum $\left(--\triangle_{--}^{-}\right)$.

in E. hoshinae and E. ictaluri may be of little importance because of the limited distribution of these species in the environment.

In contrast, $E$. tarda, a known human pathogen, produces $\beta$-lactamase ${ }^{47}$ and has wider environmental distribution. Reinhardt et al. ${ }^{15}$ also noted $\beta$-lactamase production by $29 E$. tarda strains that exhibited low MICs for $\beta$-lactam and antibiotics as did Clarke et $a l .{ }^{48}$ in a recent study of $22 E$. tarda isolates. The production of $\beta$-lactamase by $E$. tarda isolates emphasises the fact that prediction of susceptibility to $\beta$-lactam antibiotics may not be reliable. Enzyme concentration, the hydro- lytic efficiency of the enzyme, binding affinity and permeability of the outer membrane must also be considered as reasons for lack of $\beta$-lactam resistance when $\beta$-lactamase is detected. ${ }^{49}$

Five of the $10 E$. tarda isolates contained four plasmid bands ranging from $76-\mathrm{kb}$ to $5 \cdot 0-\mathrm{kb}$. Six of the 13 strains of $E$. hoshinae and one strain of $E$. tarda harboured a 54-kb plasmid of unknown function; all E. ictaluri isolates screened contained $5 \cdot 7-\mathrm{kb}$ and 4.9$\mathrm{kb}$ plasmids, confirming the findings of Lobb and Rhoades $^{20}$ and Reid and Boyle. ${ }^{50}$ No distinct pattern arose to indicate that clindamycin resistance correlated 


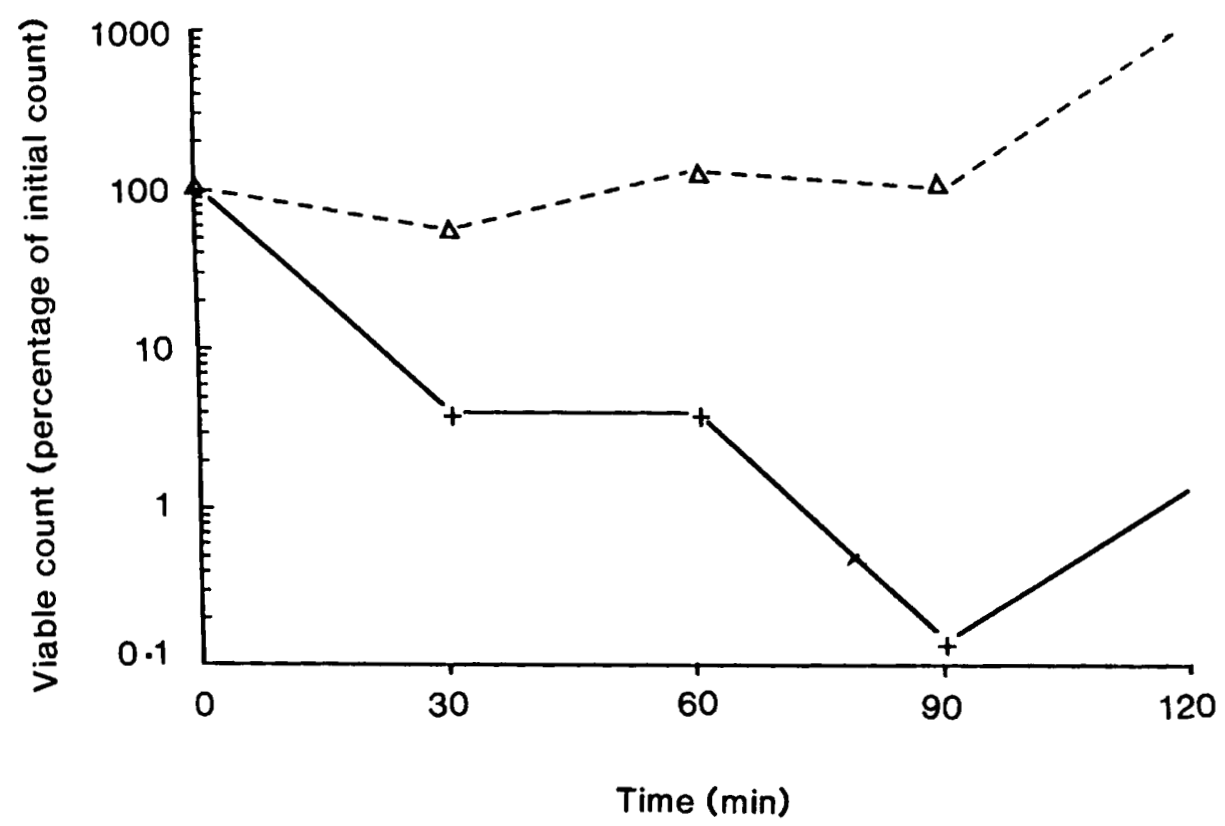

Fig. 4. Serum bactericidal susceptibility curve illustrating susceptibility of $E$. hoshinae 35051 to pooled human serum by the presence of a 10 -fold decrease in viable counts after $120 \mathrm{~min}$. PHS, $20 \%$ active serum $(-+-) ; \mathrm{HIS}, 20 \%$ inactivated serum $\left(--\triangle^{--}\right)$.

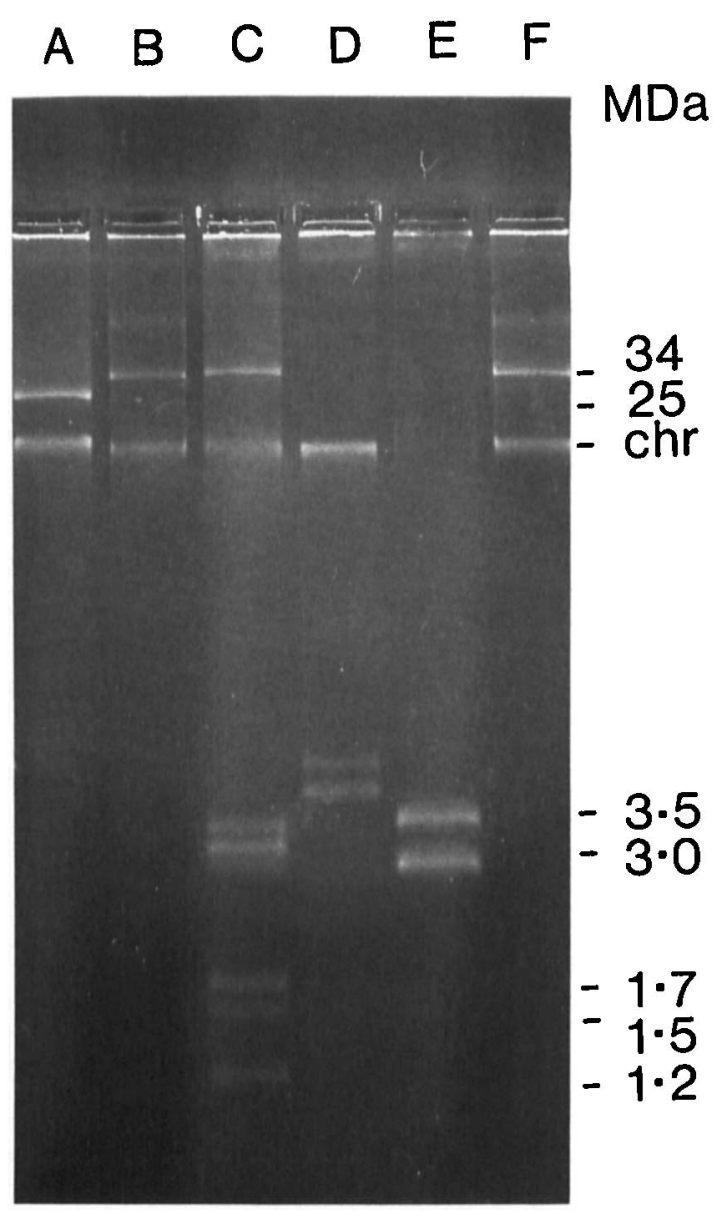

Fig. 5. Agarose gel electrophoresis of DNA lysates of Edwardsiella isolates and Escherichia coli: $15 \mu$ of lysate was electrophoresed at a constant voltage of $60 \mathrm{~V}$ in agarose $0.7 \%$. Lane $\mathbf{A}$, Esch. coli J53(sa); B, Esch. coli J53(RPH); C, Esch. coli V517(PVA 517); D, E. tarda 51778 ; E, E. ictaluri $6012 ; \mathbf{F}$, E. hoshinae (EH-1). with the presence of any of the plasmids. It is possible that testing a more extensive antibiotic profile could elucidate plasmid function in these isolates.

With one exception, all Edwardsiella spp. tested were resistant to the bactericidal effects of $20 \%$ human serum. Resistance to the killing effects of serum has been shown to correlate with the ability of bacteria to invade and survive in the bloodstream. ${ }^{36}$ The mechanism of action for the findings are unknown. Serum resistance may be mediated by the failure of complement components to integrate into the cell membrane because of the presence of repelling lipopolysaccharides or outer-membrane proteins. Some bacterial species have been found to have the ability to bind serum proteins (albumin, fibrinogen, IgG) to their surfaces and thus alter the host's ability to destroy them by serum-mediated mechanisms. ${ }^{51}$ Plasmid profiles did not correlate with serum susceptibility or resistance.

During serum bactericidal testing, E. hoshinae isolates exhibited considerably higher colony counts than expected in spite of apparent appropriate dilution as determined by spectrophotometry. This phenomenon may be secondary to cell clumping or agglutination..$^{52}$ Bergan et $a l .{ }^{26}$ have proposed that agglutination may be a useful indicator for virulence. Auto-agglutination (AA phenotype) of mesophilic aeromonads was found to be associated with higher levels of pathogenicity in mice. Therefore, auto-agglutination could be a plausible explanation for both the noted dilution phenomenon as well as the serum resistance, since autoagglutination provides a mechanism for resistance to complement-mediated lysis. ${ }^{53,54}$

Serum-resistant Edwardsiella spp. possess the ability to avoid the bactericidal effects of serum, which 
provides evidence that they could survive in vivo and to cause disease in man. Further studies may be warranted, including studies at higher serum concentrations (e.g. $60 \%$ ). As Edwardsiella sp. are found increasingly in association with immunocomprised or

\section{References}

1. Farmer JJ, McWhorter AC. Edwardsiella. In: Kreig NR, Holt JG (eds) Bergey's Manual of systematic bacteriology, vol 1. Baltimore, Williams and Wilkins. 1984: 486-91.

2. Grimont PAD, Grimont F, Richard C, Sakazaki R. Edwardsiella hoshinae, a new species of Enterobacteriaceae. Curr Microb 1980; 4: 347-351.

3. Kourany M, Vasquez MA, Saenz R. Edwardsiellosis in man and animals in Panama: clinical and epidemiological characteristics. Am J Trop Med Hyg 1977; 26: 1183-1190.

4. Kumar A, Sharma VK. Enterobacteria of emerging pathogenic significance from clinical cases in man and animals and detection of toads and wall lizards as their reservoirs. Antonie van Leeuwen J Microbiol Serol 1978; 44: 219-228.

5. Ovartlarnporn B, Chayakul P, Suma S. E. tarda infection in Hat Yai Hospital. J Med Ass Thai 1986; 69: 599-602.

6. Sechter I, Shmilovitz M, Altmann G et al. Edwardsiella tarda isolated in Israel between 1961 and 1980. J Clin Microbiol 1983; 17: 669-671.

7. Jordan GW, Hadley WK. Human infection with Edwardsiella tarda. Ann Int Med 1969; 70: 283-288.

8. Koshi G, Lalitha MK. Edwardsiella tarda in a variety of human infections. Ind J Med Res 1976; 64: 1753-1759.

9. Nagal P, Serritella A, Layden TJ. Edwardsiella tarda gastroenteritis associated with a pet turtle. Gastroenterology $1982 ; 82: 1436-1437$

10. Bockemühl J, Aleksič V, Wokatsch R, Aleksič S. Pathogenicity tests with strains of Edwardsiella tarda: detection of a heatstable enterotoxin. Zentralbl Bakteriol Mikrobiol Hyg I Abt Orig A 1983; 255: 464-471.

11. Bockemühl J, Pan-Urai R, Burkhardt F. Edwardsiella tarda associated with human disease. Pathol Microbiol $1971 ; 37$. 393-401.

12. Marsh PK, Gorbach SL. Invasive enterocolitis caused by Edwardsiella tarda. Gastroenterology 1982; 82: 336-338.

13. Clarridge JE, Musher M, Fainstein U, Wallace RJ. Extraintestinal human infection caused by Edwardsiella tarda. $J$ Clin Microbiol 1980; 11: 511-514.

14. Reinhardt JF, Fowlston S, Jones J, George WL. Comparative in vitro activities of selected antimicrobial agents against Edwardsiella tarda. Antimicrob Agents Chemother 1985; 27: 966-967.

15. Waltman WD, Shotts EB. Antimicrobial susceptibility of Edwardsiella tarda from the United States and Taiwan. Vet Microbiol 1986; 12 : 277-282.

16. Waltman WD, Shotts EB. Antimicrobial susceptibility of Edwardsiella ictaluri. J Wild Dis 1986; 22: 173-177.

17. Aoki T, Arai T, Egusa $S$. Detection of R plasmids in naturally occurring fish-pathogenic bacteria, E. tarda. Microbiol Immunol 1977; 21 : 77-83.

18. Toranzo AE, Barja JL, Colwell RR, Hetrick FM. Characterization of plasmids in bacterial fish pathogens. Infect Immun 1983; 39: 184-192.

19. Aoki T, Takahashi A. Class D tetracycline resistant determinants of R plasmids from the fish pathogens Aeromonas hydrophila, E. tarda, and Pasteurella piscicida. Antimicrob Agents Chemother 1987; 31: 1278-1280.

20. Lobb CJ, Rhoades M. Rapid plasmid analysis for identification of $E$. ictaluri from infected channel catfish (Ictalurus punctatus). Appl Environ Microbiol 1987; 53: 1267-1272.

21. Waltman WD, Shotts EB, Hsu TC. Biochemical characteristics of Edwardsiella ictaluri. Appl Environ Microbiol 1986; 51 : 101-104.

22. Janda JM, Abbott SL, Oshiro LS. Penetration and replication of Edwardsiella spp. in HEp-2 cells. Infect Immun 1991; 59: 154-161

23. Funada H, Kameoka J, Machi T, Matsuda T. Edwardsiella tarda septicemia complicating acute leukemia. Jpn J Med $1988 ; 27$ : 325-328. severely ill patients, serum resistance may provide a mechanism of action for Edwardsiella spp. to cause disease. Fortunately, as this investigation has shown, these species of bacteria are susceptible to antibiotics commonly used in medical practice.

24. Wilson JP et al. Serious infections with Edwardsiella tarda: a case report and review of the literature. Arch Intern Med 1989; 149: 208-210.

25. MacFaddin JF. Individual biochemical tests. In: Biochemical tests for identification of medical bacteria, 2nd ed, Baltimore, Williams and Wilkins. 1980: 1-320.

26. Bergan T, Lolekha S, Cheong MK, Poh CL, Doencham S, Charoenpipop D. Effect of recent antibacterial agents against bacteria causing diarrhoea. Scan J Infect Dis 1988; 56 (Suppl): 7-10.

27. Muyembe T, Vandepitte J, Desmyter J. Natural colistin resistance in Edwardsiella tarda. Antimicrob Agents Chemother 1973; 4: 521-524.

28. National Committee for Clinical Laboratory Standards. Methods for dilution antimicrobial susceptibility testing for bacteria that grow aerobically. Villanova, PA: NCCLS. 1985.

29. Thrupp LD. Susceptibility testing in liquid media. In: Lorian V (ed) Antibiotics in laboratory medicine, 2nd edn. Baltimore, Williams and Wilkins. 1986:140.

30. O'Callaghan CH, Morris A, Kirby S, Shingler A. Novel method for detection of beta-lactamase by using a chromogenic cephalosporin substrate. Antimicrob Agents Chemother $1972 ; 1: 283-288$.

31. World Health Organization Technical Report Series. Neisseria gonorrhoeae and gonnococcal infections. 1978: 616 .

32. Neu $H$. Antibiotic inactivating enzymes and bacterial resistance. In: Lorian V (ed) Antibiotics in laboratory medicine, 2nd edn. Baltimore, Williams and Wilkins. 1986: 760

33. Thornsberry C, Kirven LA. Ampicillin resistance in Haemophilus influenzae as determined by a rapid test for beta-lactamase production. Antimicrob Agents Chemother $1974 ; 6: 653-654$.

34. Montgomery K, Raymundo L, Drew WL. Chromogenic cephalosporin spot test to detect beta-lactamase in clinically significant bacteria. J Clin Microbiol 1979; 9: 205-207.

35. Wiemer CWC, Kubens B, Opferkuch W. Influence of imipenem on the serum resistance of Enterobacteriaceae. Rev Infect Dis 1985; 7 Suppl 3: S426-S431.

36. Taylor PW. Bactericidal and bacteriolytic activity of serum against gram-negative bacteria. Microbiol Rev 1983; 47: 46-83.

37. Kado CI, Liu ST. Rapid procedure for detection and isolation of large and small plasmids. $J$ Bacteriol 1981; 145: 1365-1373.

38. Birnboim HC, Doly J. A rapid alkaline extraction procedure for screening recombinant plasmid DNA. Nucleic Acids Res $1979 ; 7: 1513-1523$

39. Portnoy DA, Moseley SL, Falkow S. Characterization of plasmids and plasmid-associated determinants of Yersinia enterocolitica pathogenesis. Infect Immun 1981; 31: 775-782.

40. Gerhardt P et al. Genetics: plasmids. In: Manual of methods for general bacteriology. Washington DC, American Society for Microbiology. 1981: 269-270.

41. Meyers JA, Sanchez D, Elwell LP, Falkow S. Simple agarose gel electrophoretic method for the identification and characterization of plasmid deoxyribonucleic acid. $J$ Bacteriol 1976; 127: 1529-1537.

42. Macrina FL, Kopecko DJ, Jones KR, Ayers DJ, McCowen SM. A multiple plasmid-containing $E$. coli strain: convenient source of size reference plasmid molecules. Plasmid $1978 ; 1: 417-420$

43. Miller MA, Kuemmerle NB, Gentile G. Amoxicillin and ampicillin: a comparative study of in vitro sensitivity and induced morphological alteration in Serratia marcescens. Jpn J Microbiol 1975; 19: 219-224.

44. Lorian V. Effect of low antibiotic concentrations on bacteria effects on ultrastructure, their virulence and susceptibility 
to immunodefenses. In: Lorian $\mathrm{V}$ (ed) Antibiotics in laboratory medicine. Baltimore, Williams and Wilkins. 1980: 596-668.

45. Hayat MA. Fixation and embedding. In: Hayat GA (ed) Principles and techniques of electron microscopy, vol. 1 New York, Litton Educational Publishers Inc. 1970: 1-178.

46. Perkins RL, Miller MA. Scanning electron microscopy of morphological alterations in Proteus mirabilis induced by cephalosporins and semisynthetic penicillins. Can $J$ Microbiol 1973; 19: 251-255.

47. Reger PJ, Mockler D, Janda JM, Brenden R, Miller MA. Comparison of antibiotic susceptibility and beta-lactamase production in Edwardsiella hoshinae to tarda and ictaluri. Abstracts of the American Society for Microbiology, 1990: 13.

48. Clark RB, Lister PD, Janda JM. In vitro susceptibilities of Edwardsiella tarda to 22 antibiotics and antibiotic- $\beta$ lactamase-inhibitor agents. Diagn Microbiol Infect Dis 1991; 14: 173-175.

49. Bush K, Sykes RB. Interaction of beta-lactam antibiotics with beta-lactamases as a cause for resistance. In: Bryan LE (ed) Antimicrobial drug resistance. New York, Academic Press. 1984: 1-31.

50. Reid WS, Boyle JA. Plasmid homologies in Edwardsiella ictaluri. Appl Environ Microbiol 1989; 55: 3253-3255.

51. Miörner H, Myhre E, Björck L, Kronvall G. Effect of specific binding of human albumin, fibrinogen, and immunoglobulin $\mathrm{G}$ on surface characteristics of bacterial strains as revealed by partition experiments in polymer phase systems. Infect Immun 1980; 29: 879-885.

52. Janda JM, Oshiro LS, Abbott SL, Duffey PS. Virulence markers for mesophilic Aeromonads: association of the autoagglutination phenomenon with mouse pathogenicity and the presence of a peripheral cell-associated layer. Infect Immun 1987; 55: 3070-3077.

53. Mittal KR, Lalonde G, Leblanc D, Olivier G, Lallier R. Aeromonas hydrophila in rainbow trout: relation between virulence and surface characteristics. Can J Microbiol 1980; 26: 1501-1503.

54. Wong JD, Miller MA, Janda J. Surface properties and ultrastructure of Edwardsiella species. J Clin Microbiol 1989; 27: 1797-1801. 